\title{
ANALISIS TINGKAT LITERASI LINGKUNGAN SISWA PADA MUATAN LOKAL PENDIDIKAN LINKUNGAN HIDUP
}

\author{
Nur Aini ${ }^{2 *}$, Mimien Henie Irawati Al Muhdhar ${ }^{1}$, Fatchur Rochman ${ }^{1}$, I Wayan Sumberartha ${ }^{1}$, Lely \\ Mardiyanti ${ }^{1}$, Wenny Wardhani ${ }^{2}$ \\ ${ }^{1}$ Universitas Negeri Malang, Jalan Semarang No. 5, Malang, Jawa Timur. \\ ${ }^{2}$ SMA Negeri 3 Jombang, Jalan Dr. Sutomo No. 75, Jombang, Jawa Timur. \\ * corresponding author | email : nuraini.biologium@gmail.com
}

\begin{abstract}
Dikirim Tanggal Bulan Tahun
Diterima Tanggal Bulan Tahun

Diterbitkan Tanggal Bulan Tahun

ABSTRAK

doi http://dx.doi.org/10.17977/um052v12i1p40-44

Tujuan dari penelitian ini adalah untuk mengetahui tingkat literasi lingkungan siswa kelas X IPA 1 SMAN 3 Jombang pada muatan lokal pendidikan lingkungan hidup. Penelitian ini tergolong deskriptif kualitatif. Populasi penelitian adalah seluruh siswa kelas X IPA SMAN 3 Jombang. Sampel penelitian ditentukan dengan purposive sampling yaitu kelas X IPA 1. Hasil penelitian dijabarkan sebagai berikut, literasi lingkungan siswa termasuk dalam kategori cukup dengan rerata skor sebesar 75 . Indikator pengetahuan termasuk dalam kategori baik dengan rerata skor 80. Indikator keterampilan kognitif, sikap, dan perilaku termasuk dalam kategori cukup dengan masing-masing rerata skor yaitu 75,74 , dan 72 . Pembelajaran pada muatan lokal pendidikan lingkungan hidup berdampak pada peningkatan literasi lingkungan siswa akan tetapi tidak memberikan perbedaan yang signifikan.
\end{abstract}

\section{Keyword : literasi lingkungan, muatan lokal, pendidikan lingkungan hidup}

The aim of this study was to determine the level of environmental literacy of students class X Science 1 of SMAN 3 Jombang on the local content of environmental education. This research is classified as qualitative descriptive. The study population was all students of class X IPA SMAN 3 Jombang. The research sample was determined by purposive sampling, namely class X IPA 1 . The results of the study are described as follows, environmental literacy of students is included in the category of sufficient with a mean score of 75. Indicators of ecological knowledge are categorized well with a mean score of 80 . Indicators of cognitive skills, attitudes, and behavior included in the category enough with each average score of 75,74 , and 72 . Learning on the local content of environmental education has an impact on increasing environmental literacy of students but does not make a significant difference.

\section{Keyword : environtmental literacy, local content, environtmental education}


Berbagai permasalahan lingkungan yang terjadi semakin memprihatinkan, mulai dari masalah polusi udara, penggundulan hutan, menipisnya lapisan ozon, pemanasan global, hingga perubahan iklim yang ekstrim (Nunez \& Clores, 2017). Kurangnya wawasan tentang lingkungan yang dimiliki seseorang menyebabkan berbagai permasalahan lingkungan terus terjadi tanpa disadari para pelaku perusakan. Solusi terhadap berbagai permasalahan lingkungan harus datang dari semua disiplin ilmu, terutama yang paling mendasar adalah dunia pendidikan. Salah satu indikator peduli lingkungan dapat diukur melalui tingkat literasi lingkungan (Hermawan, 2018). Miller (2010) dalam Gayford (2002), mendefinisikan literasi lingkungan sebagai kemampuan untuk mengenali bahwa pilihan seseorang berdampak pada lingkungan; untuk mengidentifikasi solusi yang paling berkelanjutan untuk suatu masalah; dan untuk dapat bertindak dengan cara yang paling ramah lingkungan pada solusi itu. North American Association for Environmental Education (2000) telah menetapkan pedoman untuk mengukur kemampuan literasi lingkungan yang terdiri dari empat bagian yaitu pengetahuan ekologi, keterampilan kognitif, sikap dan perilaku terhadap lingkungan (Mcbride, 2013).

Semua siswa, sebagai konsumen masa depan, perlu mengetahui tentang masalah lingkungan dan bagaimana membantu menciptakan dunia yang sehat lingkungan dan lebih manusiawi. Siswa yang memiliki literasi lingkungan akan dapat bertanggung jawab terhadap lingkungan melalui pengetahuan, keterampilan, dan kesadaran akan masalah lingkungan (Gayford, 2002). Namun, selama ini tingkat literasi lingkungan siswa di Indonesia secara kumulatif masih perlu ditingkatkan. Pengetahuan dan keterampilan kognitif siswa terhadap lingkungan berada pada kategori tinggi, sementara sikap dan perilaku siswa berada pada kategori sedang (Maulidya, 2014). Pendidikan Lingkungan Hidup merupakan upaya untuk mengubah perilaku dan sikap untuk meningkatkan pengetahuan, keterampilan dan kesadaran seseorang tentang nilai-nilai dan isu permasalahan lingkungan yang pada akhirnya dapat menggerakkan masyarakat untuk berperan aktif dalam upaya pelestarian dan keselamatan lingkungan (UNNES, 2014).

Saltan \& Divarci (2017) dalam penelitiannya menyebutkan bahwa kegiatan pendidikan lingkungan dapat meningkatkan tingkat literasi lingkungan siswa. Oleh karena itu, peneliti ingin menganalisis kemampuan literasi lingkungan siswa yang memperoleh muatan lokal pendidikan lingkungan hidup untuk mengetahui sejauh mana pendidikan lingkungan dapat meningkatkan literasi lingkungan siswa.

\section{METODE}

Metode penelitian yang digunakan dalam penelitian ini adalah metode penelitian deskriptif. Penelitian dilakukan di SMAN 3 Jombang dengan sampel penelitian adalah siswa kelas X IPA 1 yang berjumlah 36 siswa. Data penelitian berupa skor literasi lingkungan siswa yang diperoleh melalui metode tes. Tes dilakukan sebagai posttest diakhir siklus pembelajaran, yang dalam penelitian ini dilakukan selama dua siklus. Instrument yang digunakan dalam kegiatan tes ini diadaptasi dari soal tes Middle Schools Environment Survey/Instrument (MSELS/I) oleh NELA (2008), yang telah disesuaikan dan telah di uji coba pada populasi yang sama dengan sampel yang berbeda untuk mengukur validitas, dan reliabilitas. Transformasi skor mentah hasil tes literasi lingkungan secara lengkap tersaji dalam Tabel 1. Sedangkan Untuk menentukan kriteria skor untuk tiap indikator disesuaikan dengan PAP SMAN 3 Jombang, yang disajikan dalam Tabel 2. 
Tabel 1. Kisi-Kisi Penskoran Instrumen Literasi Lingkungan

\begin{tabular}{|c|c|c|c|c|c|c|c|}
\hline $\begin{array}{l}\text { Indikator literasi } \\
\text { lingkungan }\end{array}$ & Sub indikator & Bentuk tes & $\begin{array}{l} \\
\text { soal } \\
\end{array}$ & $\begin{array}{l}\text { Faktor } \\
\text { pengali }\end{array}$ & Skor & $\begin{array}{l}\text { Total } \\
\text { Skor }\end{array}$ & $\begin{array}{l}\text { Kisaran } \\
\text { Skor }\end{array}$ \\
\hline $\begin{array}{l}\text { Pengetahuan } \\
\text { ekologi }\end{array}$ & Pengetahuan ekologi & $\begin{array}{l}\text { Pilihan } \\
\text { ganda }\end{array}$ & 17 & 5,9 & 100,3 & 100 & $0-100$ \\
\hline \multirow{2}{*}{$\begin{array}{l}\text { Keterampilan } \\
\text { kognitif }\end{array}$} & $\begin{array}{l}\text { Identifikasi isu } \\
\text { lingkungan }\end{array}$ & $\begin{array}{l}\text { Pilihan } \\
\text { ganda }\end{array}$ & 2 & 12,5 & 25 & \multirow{2}{*}{100} & \multirow{2}{*}{$0-100$} \\
\hline & Analisis isu lingkungan & $\begin{array}{l}\text { Pilihan } \\
\text { ganda }\end{array}$ & 6 & 12,5 & 75 & & \\
\hline \multirow{2}{*}{$\begin{array}{l}\text { Sikap terhadap } \\
\text { lingkungan }\end{array}$} & $\begin{array}{l}\text { Komitmen terhadap } \\
\text { lingkungan }\end{array}$ & $\begin{array}{l}\text { Angket } \\
\text { pernyataan }\end{array}$ & 12 & 5 & 60 & \multirow{2}{*}{150} & \multirow{2}{*}{$30-150$} \\
\hline & $\begin{array}{l}\text { Kepekaan terhadap } \\
\text { lingkungan }\end{array}$ & $\begin{array}{l}\text { Angket } \\
\text { pernyataan }\end{array}$ & 18 & 5 & 90 & & \\
\hline $\begin{array}{l}\text { Perilaku } \\
\text { terhadap } \\
\text { lingkungan }\end{array}$ & Komitmen nyata & $\begin{array}{l}\text { Angket } \\
\text { pernyataan }\end{array}$ & 12 & 5 & 60 & 60 & $12-60$ \\
\hline
\end{tabular}

Diadaptasi dari NELA (2008).

Tabel 2. Kriteria Literasi Lingkungan

\begin{tabular}{ccc}
\hline No. & Presentase & Kriteria \\
\hline 1. & $90-100$ & A (Sangat Baik) \\
\hline 2. & $80-89$ & B (Baik) \\
\hline 3. & $70-79$ & C (Cukup Baik) \\
\hline 4. & $0-79$ & D (Kurang Baik) \\
\hline
\end{tabular}

Sumber: PAP SMAN 3 Jombang

\section{HASIL DAN PEMBAHASAN}

Data hasil tes literasi lingkungan siswa kelas X IPA 1 pada masing-masing siklus secara ringkas disajikan dalam Tabel 3 dan Tabel 4.

Tabel 3. Nilai Literasi Lingkungan Siswa Siklus I

\begin{tabular}{lcl}
\multicolumn{1}{c}{ Indikator } & Nilai & Kriteria \\
\hline Pengetahuan ekologi & 72 & Kurang \\
\hline Keterampilan kognitif & 69 & Kurang \\
\hline Sikap & 67 & Kurang \\
\hline Perilaku & 69 & Kurang \\
\hline Literasi lingkungan & 69 & Kurang \\
\hline
\end{tabular}

Tabel 4 Nilai Literasi Lingkungan Siswa Siklus II

\begin{tabular}{lcc}
\hline \multicolumn{1}{c}{ Indikator } & Nilai & Kriteria \\
\hline Pengetahuan ekologi & 80 & Baik \\
\hline Keterampilan kognitif & 75 & Cukup \\
\hline Sikap & 72 & Cukup \\
\hline Perilaku & 74 & Cukup \\
\hline Literasi lingkungan & 75 & Cukup \\
\hline
\end{tabular}

Berdasarkan Tabel 3 dan Tabel 4, diketahui bahwa hasil tes literasi lingkungan siswa menunjukkan bahwa pada tes siklus pertama, tingkat literasi lingkungan siswa berkategori kurang dan pada tes siklus kedua tingkat literasi lingkungan siswa berkategori cukup. Terdapat peningkatan hasil tes literasi lingkungan pada siklus II jika dibandingkan dengan siklus I, namun peningkatan ini tidak terlalu signifikan.

Berdasarkan rerata nilai pada setiap indikator literasi lingkungan pada masing-masing siklus diketahui bahwa pendidikan lingkungan hidup dapat meningkatkan literasi lingkungan siswa. Namun, kegiatan pembelajaran pada muatan lokal pendidikan lingkungan hidup tidak memberikan 
perbedaan yang signifikan terhadap tingat literasi lingkungan siswa. Hasil penelitian menunjukkan bahwa indikator pengetahuan ekologi memiliki skor yang paling tinggi, sementara indikator sikap memiliki skor paling rendah.

Haske dan Wulan (2015), menyatakan bahwa perolehan skor pengetahuan dasar ekologi siswa yang tinggi dapat dipengaruhi oleh tingkat kognitif siswa dan adanya konsep yang telah diajarkan oleh guru. Dalam penelitiannya juga disampaikan bahwa pendidikan lingkungan harus mengembangkan pemahaman tentang sistem ekologi, dan sebab-akibat hubungan antara sikap dan perilaku manusia terhadap lingkungan. Sementara indikator sikap, memiliki nilai yang paling rendah hal ini dikarenakan banyak faktor yang dapat mempengaruhi sikap siswa terhadap lingkungan seperti orang tua, kurikulum sekolah, dan kebiasaan siswa dirumah. (Maulidya, 2014). Sikap seseorang terhadap lingkungan dibentuk dalam interaksi secara terus-menerus dengan orang lain, lingkungan, serta budaya, ketiganya memiliki efek yang lebih berpengaruh terhadap sikap seseorang (Eagles \& Demare, 1999).

Indikator keterampilan kognitif memiliki nilai yang cukup. Hal ini dikarenakan pembelajaran dengan menekankan kegiatan pada kondisi nyata lingkungan disekitar siswa, dapat membuka wawasan berpikir siswa yang beragam dalam memecahkan suatu permasalahan (Ardianti, dkk., 2017). Indikator perilaku memiliki skor yang cukup dan mengalami peningkatan, hal ini dikatenakan pengetahuan yang tertanaman pada siswa akan mempengaruhi sikapnya terhadap lingkungan yang akan diwujudkan dalam suatu tindakan atau perilaku yang mendukung lingkungan (Haske dan Wulan, 2015). Selain itu, pengalaman belajar yang diperoleh siswa secara langsung dari lingkungan dapat meningkatkan perilaku terhadap lingkungan (Ardianti, dkk., 2017).

Secara keseluruhan, kegiatan pembelajaran pada muatan lokal pendidikan lingkungan hidup tidak memberikan perbedaan yang signifikan terhadap tingat literasi lingkungan siswa. Istikomayanti, dkk., (2016) menyatakan bahwa kemampuan literasi lingkungan siswa yang masih rendah dapat disebabkan belum adanya lingkungan di sekolah yang mampu menyediakan pengalaman belajar langsung kepada siswa untuk berinteraksi dengan lingkungan. Haske dan Wulan (2015), menyatakan, dalam rangka mengembangkan literasi lingkungan siswa, pendidikan lingkungan harus mengembangkan pemahaman tentang sistem ekologi, sebab-akibat hubungan antara sikap dan perilaku manusia terhadap lingkungan, serta menumbuhkan perilaku bertanggungjawab terhadap lingkungan.

\section{KESIMPULAN DAN SARAN}

\section{Kesimpulan}

Berdasarkan hasil penelitian dapat disimpulkan bahwa pembelajaran pada muatan local pendidikan lingkungan hidup berdampak positif dalam meningkatkan literasi lingkungan siswa. Namun, tidak memberikan perbedaan hasil yang signifikan terhadap tingkat literasi lingkungan siswa.

\section{Saran}

Pembelajaran pada muatan local pendidikan lingkungan hidup sebaiknya ditekankan pada pengetahuan mengenai sistem ekologi, dan sebab-akibat hubungan dampak aktivitas manusia terhadap lingkungan sehingga diharapkan dapat memberikan dampak terhadap tingkat literasi lingkungan siswa.

\section{DAFTAR RUJUKAN}

Ardianti, S.D., Wanabuliandri, A., \& Rahardjo, S. 2017. Peningkatan Perilaku Peduli Lingkungan dan Tanggung Jawab Siswa Melalui Model EJAS Dengan Pendekatan Science Edutainment. Jurnal Ilmiah Pendidikan Dasar, 4(1).

Eagles, P.F.J. \& Demare, R. 199. Factors Influencing Children's Environmental Attitudes. The Journal of Environmental Education, 30(4): 33-37.

Gayford, C.G. 2002. Environmental Literacy: towards ashared understanding for science teachers. 
Research in Science \& Technological Education 20(1): 99-110.

Haske, A.S., \& Wulan, A.R. 2015. Pengembangan E-learning berbasis MOODLE dalam Pembelajaran Ekosistem untuk Meningkatkan Literasi Lingkungan Siswa pada Program Pengayaan. Jurnaal Biologi, Sains, Lingkungan, dan Pembelajarannya, 8(9): 402-409.

Hermawan, I.M.S., \& Susilo, H. 2018. Konsep Literasi Lingkungan Dalam Perspektif Budaya Tri Hita Karana Masyarakat Bali: Sebuah Kajian Literatur. Prosiding Seminar Nasional Pendidikan Biologi.

Istikomayanti, Y., Suwono, H., \& Irawati, M.H. 2016. Pembelajaran Eksperensial Group Investigation (GI) Sebagai Upaya Mengembangkan Kemampuan Literasi Lingkungan Siswa Kelas IV MI. Jurnal Pendidikan Biologi Indonesia, 2(1): 57-71.

Maulidya, F., Mudzakir, A., \& Sanjaya, Y. 2014. Case Study the Environmental Literacy of Fast Learner Middle School Students in Indonesia. International Journal of Science and Research, 3(1).

McBride, M.M., Brewer, C.A., Berkowitz, A.R., dan Borrie, W.T. 2013. Environmental literacy, ecological literacy, ecoliteracy:What do we mean and how did we get here?. Ecoshpere Journal 4(5): 1-20

NELA. 2008. National Environmental Literacy Assessment Project: Year 1, National Baseline Study of Middle Grades Students Final Research Report. USA.

Nunez, M.B., \& Clores, M.A. 2017. Environmental Literacy of K-10 Student Completers. International Journal Of Environmental \& Science Education, 12(5): 1195-1215.

UNNES. 2014. Pendidikan Lingkungan Hidup (Buku Ajar Mata Kuliah Umum). Pusbang MKU/MKDK Universitas Negeri Semarang.

Saltan, F. \& Divarci, O.F. 2017. Using Blogs to Improve Elementary School Student's Environmental Literacy in Science Class. European Journal of Educational Research, 6(3): 347-355. 